\title{
Third-Party Certification of Forest Management In Indonesia: Analysing Stakeholders' Recognition and Preferences
}

\author{
Santi Pratiwi ${ }^{1,3^{*}}$, Agung Wibowo ${ }^{2,3}$, Lukas Giessen $^{3}$ \\ ${ }^{1}$ South Sumatera Nature Conservation Agency, Ministry of Environment and Forestry, Jl. Kol. H. Burlian KM 6 No. 79 \\ Puntikayu, Palembang, Indonesia 30153 \\ ${ }^{2}$ Department of Forestry, Faculty of Agriculture, University of Palangka Raya, Kampus UNPAR Tunjung Nyaho, Jl. Yos \\ Sudarso PO Box 2/PLKUP, Palangka Raya, Indonesia 73111 \\ ${ }^{3}$ Chair of Forest and Nature Conservation Policy, Georg-August-Universität Goettingen, Buesgenweg 3, Goettingen, Germany \\ 37077
}

Received May 20, 2015/Accepted July 28, 2015

\begin{abstract}
The existence of third-party forest and timber certification schemes in Indonesia has created benefits and challenges, mainly for forest industries. In the end, the interests and objectives of those industries will determine whether they decide to get certified and if so, what certification schemes they will use. This study analyses the stakeholder recognition of the competing forest legality and sustainability certification systems and describes the preferences for particular schemes based on stakeholder interests. Online questionnaires were distributed to relevant stakeholders, namely logging companies, wood processing industries, wood processing associations, auditors, academics, environmental organisations and government officials. The results indicate that there are different scheme preferences based on the stakeholder's interests. Sistem verifikasi legalitas kayu (SVLK) is the most frequently preferred scheme due to the simplicity of its requirements and the low cost of its certifying process, while the Forest stewardship council (FSC) is valued for its reputation and very high standards. Furthermore, lembaga ekolabel Indonesia (LEI) was least preferred because of its complexity and because it was unpopular with foreign end buyers, and the programme for the endorsement offorest certification (PEFC) was identified as being a complex scheme that was expensive and subject to high standards, and also appeared to have the least demand. Each scheme should be improved based on stakeholders' expectations, that their popularity with end buyers of timber products should be improved, and that this should be done in a way that allows logging and wood processing industries to choose freely the scheme that is most advantageous to them
\end{abstract}

Keywords: forest certification schemes, timber legality system, preferences, forest and timber industries

*Correspondence author, email: santi.pratiwi04@gmail.com, tel: +62-85998057975

\section{Introduction}

Forest certification is an information tool and a marketbased instrument (Upton \& Bass 1995; Rametsteiner \& Simula 2003) that ensures that the forest and its management conform to a particular standard (Nussbaum \& Simula 2005). Forest certification was initially advanced by environmental groups as a response to the consequences of deforestation and forest degradation in the early 90s (Rametsteiner \& Simula 2003; Leslie 2004). A massive campaign to produce and use only certified timber products has turned forest certification into a new form of governance in international trade and business (Haufler 2003; van Kooten et al. 2005).

Currently, there are 3 entities providing voluntary-private forest certification schemes in Indonesia, namely the forest stewardship council (FSC), the programme for the endorsement of forest certification (PEFC, implemented by the indonesian forest certification cooperation or IFCC), and the Indonesian ecolabelling institute or lembaga ekolabel Indonesia (LEI). In addition, there is one mandatory state forest and timber legality certificate system, namely the timber legality verification system or sistem verifikasi legalitas kayu (SVLK, including the sustainable production forest management scheme or pengelolaan hutan produksi lestari/PHPL). By 2014, there were 2,002,710 ha of forest that had been certified under the FSC scheme, adding 193 chain of custody (CoC) certificates for wood-based industries across the country (FSC 2014). In the same year 17 PEFC-based CoC certificates (PEFC 2014) were also issued, as were 39 sustainability certificates for $1,970,175$ ha of forest and $6 \mathrm{CoC}$ certificates using the LEI scheme (LEI 2014), in addition to 826 legality certificates for wood processing industries (SILK 2014).

The existence of many third-party certification schemes has created benefits and barriers for the stakeholders 
involved (Thornber et al. 1999; Hansen et al. 2005), especially logging companies and the wood processing industry. In theory, the existence of many options would make it easy for stakeholders to choose a scheme that best suits their interests and needs (Gulbrandsen 2003). Tuppura et al. (2015) have described a number of motivations forest companies may have for becoming certified, namely authorities' orders, clients' wishes, improving their image, distinguishing themselves from their competitors, opening new markets, increasing internal control, and risk management and long-term profitability. The selection of favourable certification schemes by the companies is not always easy, due to some of the constrains they face, e.g., complexity of certification requirements, lack of verification/certification bodies, limited amount of financial subsidies (Obidzinski et al. 2014), unclear land use regimes (Sahide et al. 2015), the cost of certification, schemes' legitimacy (Nurrochmat et al. 2014), market orientation and the schemes' acceptability (Wibowo et al. 2014).

The dilemma faced by industries has become more complicated since the government decided to make SVLK mandatory for all logging companies and wood processing industries (MoE Regulation Number 38/2009). It is within this context that we assess stakeholders' recognition of and preferences for third party forest certification schemes in Indonesia. Our main research questions are:

(i) what schemes do businesses prefer?

(ii) what criteria do businesses consider, in making their selection?

\section{Methods}

Businesses' motivations for becoming certified were gleaned from the FSC (2008), Faggi et al. (2014), Lozano (2013) and Tuppura et al. (2015). From this close-ended questionnaires that included additional aspects that may apply in Indonesia. In addition, an open space for personal opinion were provided.

The key respondents were those who had been involved with the legality verification system in Indonesia and were therefore familiar with it. The respondents were categorised into main respondents, which consisted of those from logging companies (LC), from the wood processing industry (WPI) and from the wood processing association (WPA), and supporting respondents, which consisted of auditors, environmental organisation representatives, academics, and government officials. These respondent groups were chosen due to their strong interests (Krott 2005) and influences (Steffek 2009) in forest governance.

The questionnaires were divided into 3 types, one each for (i) LC and WPI, (ii) WPA, and (iii) supporting respondents. The questionnaires consisted of two sections. The first, General Information, included the name of the respondent, the type of respondent (type of stakeholder), workplace, and contact information. The second, Stakeholder Preferences, consisted of the respondents' experiences and perceptions of each of the four schemes' characteristics, e.g., their market acceptance, the complexity of their requirements, and the ease with which certificates from each could be obtained. The questionnaires were sent to the respondents along with introductory and personal information in the body of an email. The online questionnaires were distributed in January and February 2015 through personal email, mailing lists, association channels, and social media. Out of 508 personal emails sent 108 replies $(21 \%)$, comprising stakeholders from logging companies ( 23 persons), from the wood processing industry (23 persons), from the wood processing association (7 persons), auditors (22 persons), environmental organisation representatives (18 persons), academics (11), and government officials/Ministry of Environment and Forestry employees (MoEF) (4 persons). Eight respondents replied and did not fill the questionnaires due to lack of updated knowledge and company privacy. The data obtained from the questionnaires were tabulated into an Excel file database and the answers for each of the closed questions were transformed into bar and pie charts.

\section{Results and Discussion}

From the questionnaires were sent, we found stakeholders' recognition of and preferences for certification and timber legality systems as seen in Table 1.

Table 1. Key features of stakeholders' recognition of and preferences for certification and timber legality systems

\begin{tabular}{|c|c|c|c|c|}
\hline \multirow[t]{2}{*}{ Key features } & \multicolumn{4}{|c|}{ Ranking } \\
\hline & 1 & 2 & 3 & 4 \\
\hline Ease of procurement & SVLK & LEI & FSC & PEFC \\
\hline Complexity of requirements & FSC & PEFC & LEI & SVLK \\
\hline Quality of standards & FSC & PEFC & LEI & SVLK \\
\hline Demand by customer s of timber producer & SVLK & FSC & PEFC & LEI \\
\hline Demand by end buyer & FSC & PEFC & SVLK & LEI \\
\hline Help to industries and logging companies & FSC & LEI & PEFC & SVLK \\
\hline Good image branding & FSC & PEFC & SVLK & LEI \\
\hline Necessary for Indonesia's conditions & SVLK & FSC & LEI & PEFC \\
\hline Suitability for Indonesia's conditions & LEI & SVLK & FSC & PEFC \\
\hline Preferred by stakeholders & SVLK & FSC & PEFC & LEI \\
\hline
\end{tabular}

FSC $=$ Forest Stewardship Council, PEFC = Programme for the Endorsement of Forest Certification, LEI = Lembaga Ekolabel Indonesia

$\mathrm{SVLK}=$ Sistem Verifikasi Legalitas Kayu 
was not easy due to the many challenges involved. According to the respondents, LEI is easier because of its assessment system.

A similar trend is seen in the WPI group, where $69 \%$ and $57 \%$ said that SVLK and LEI are easier to obtain. The rest of the group, $48 \%$ and $31 \%$, said that the FSC and PEFC are easier to obtain. The trend is quite different for WPA respondents, where SVLK (71\%), FSC (58\%), LEI (57\%) and PEFC (29\%) were considered to be easy to obtain. The WPA and WPI respondents believe that SVLK is the easiest certificate to obtain, because the SVLK is a mandatory

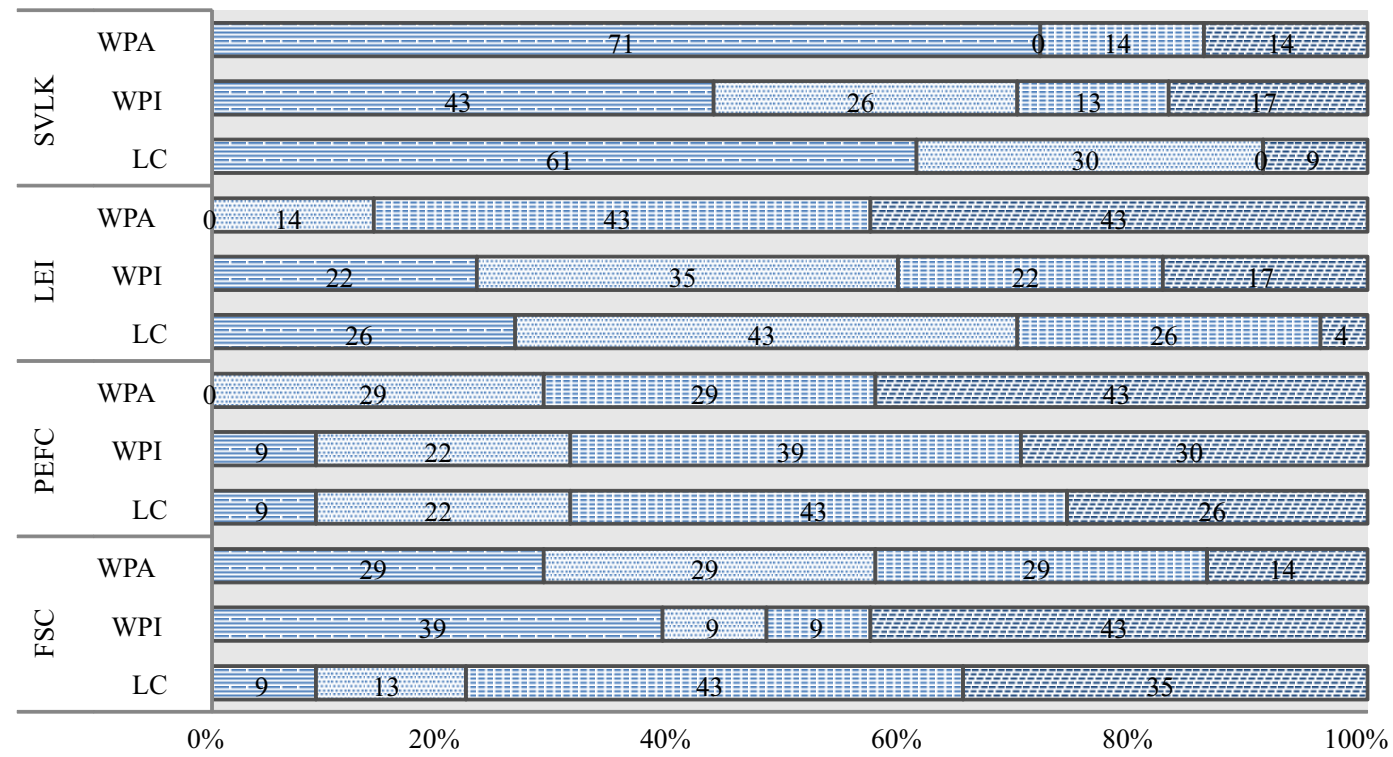

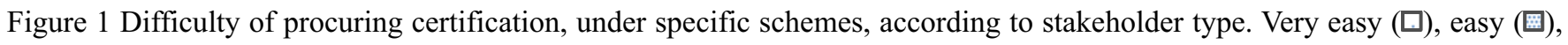
intermediate (回), more dificult (回).

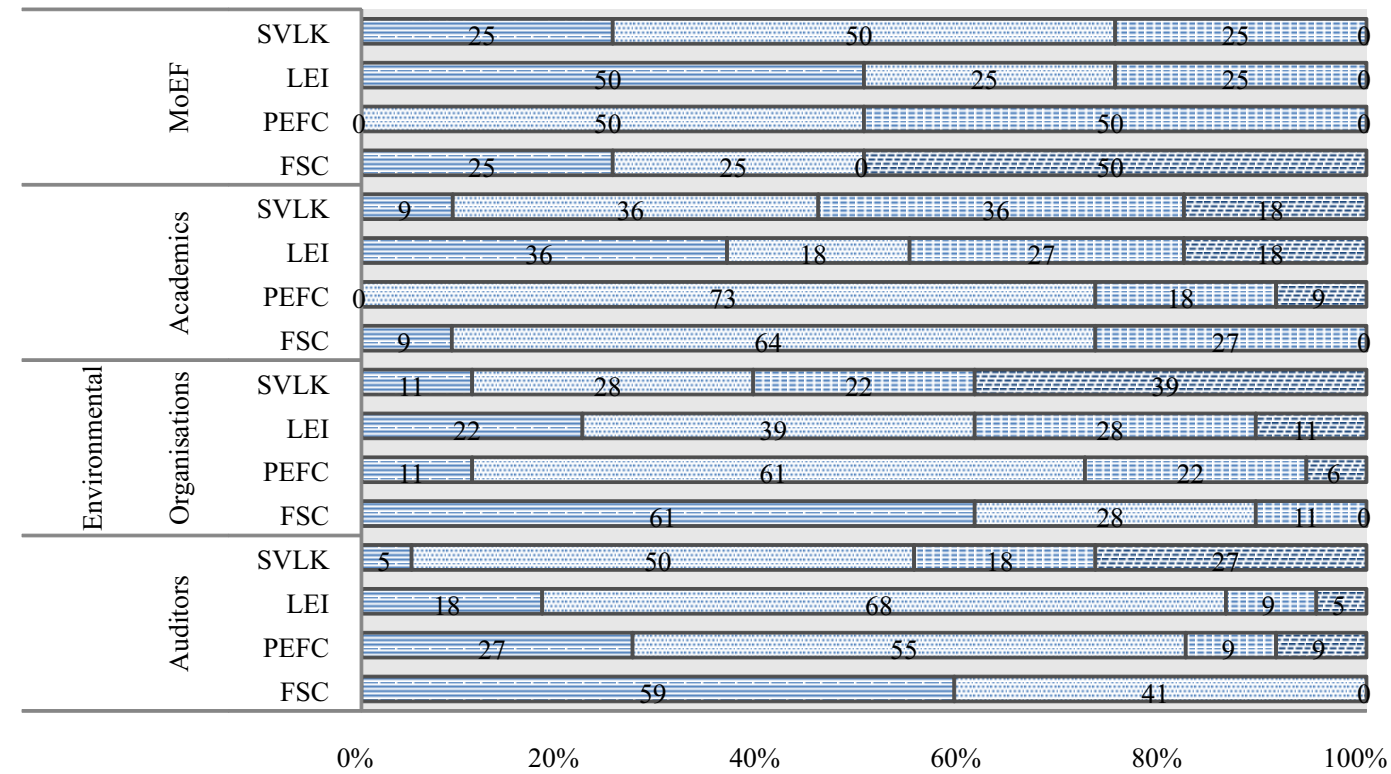

Figure 2 The perceived complexity of the schemes, according to stakeholder type. Very complex (目), Complex (圆), Intermediate (田), Simpler (国). 
arrangement established by the government, has clear indicators, criteria and verifiers and is easier to apply. The SVLK is also cheaper because the cost of certification for a smallholder company can be paid by the Ministry of Environment and Forestry (MoEF Regulation Number 95/2014). In addition, SVLK standards are simpler.

Complexity of requirements Almost all respondents in the four groups agreed that FSC standards are more complex than those of the PEFC, LEI and SVLK (Figure 2). In the auditors group, all respondents (100\%) thought that the FSC is the most complex standard, followed by the LEI $(86 \%)$, PEFC (82\%) and SVLK (55\%). A similar trend was shown for the environmental organisations, where the respondents thought that the FSC $(89 \%)$ and PEFC $(72 \%)$ were more complex than the LEI (61\%) and SVLK (39\%). The same trend is observed in the academics group, where the respondents answered that the FSC (73\%) and PEFC (73\%) are more complex than the LEI (54\%) and SVLK (45\%). The respondents from the government official group thought that the LEI (75\%) and the SVLK $(75 \%)$ are more complex than the FSC (50\%) and PEFC (50\%).

The FSC is the most difficult certificate to get, and the scheme involved is even impossible for some industries. One of the respondents said that FSC uses political judgments in establishing forest certification rules so as to protect their market from the new certification schemes, so that the environmentally friendly wood products had to be associated with and certified by the FSC. This opinion is also supported by the results showing that the FSC has the highest standards of all schemes, which implies difficulties in procuring the corresponding certificate (Taylor 2005, Nukpezah et al. 2014). FSC standards are complex and adhere strictly to the principles, criteria and indicators of FSC International. However, the certification body can make FSC standards become easier or more difficult to comply with, since it has

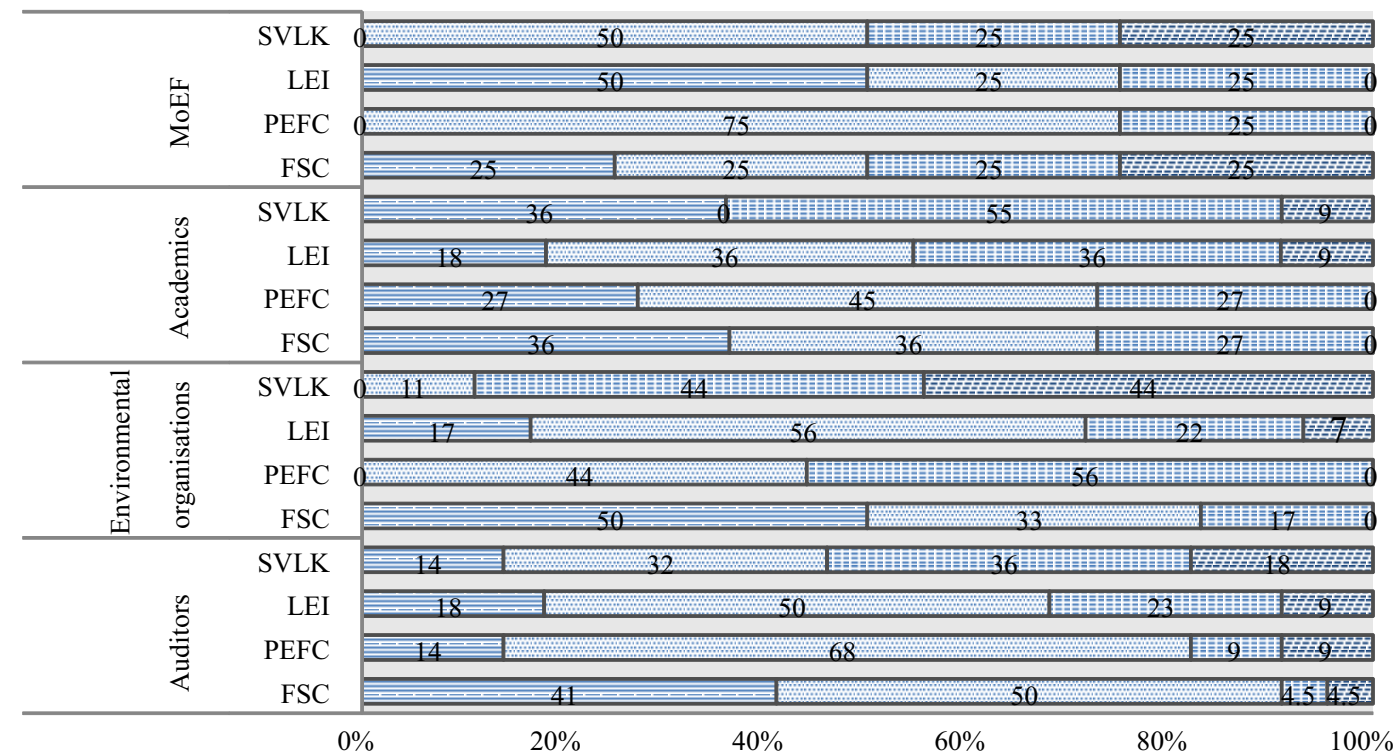

Figure 3 The quality of each scheme's standards, according to stakeholder type. Very high (目), high (䊡), intermediate (国), low (国).

Wood Processing Associations

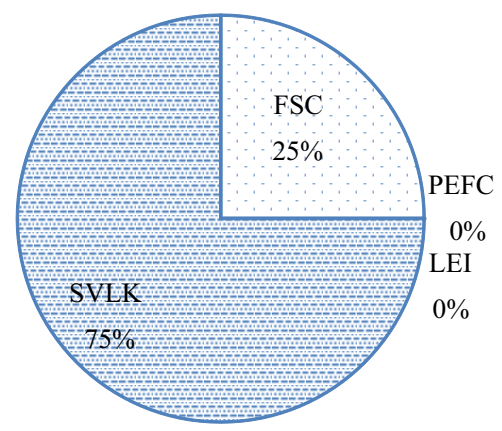

Logging Companies

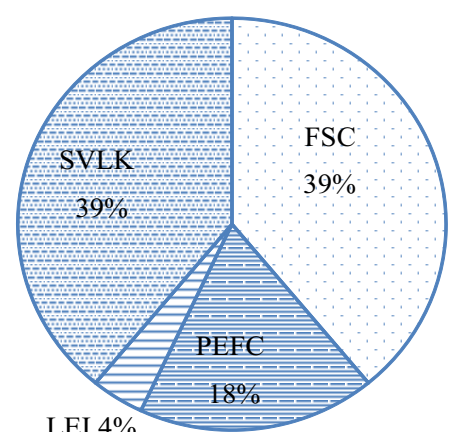

LEI $4 \%$

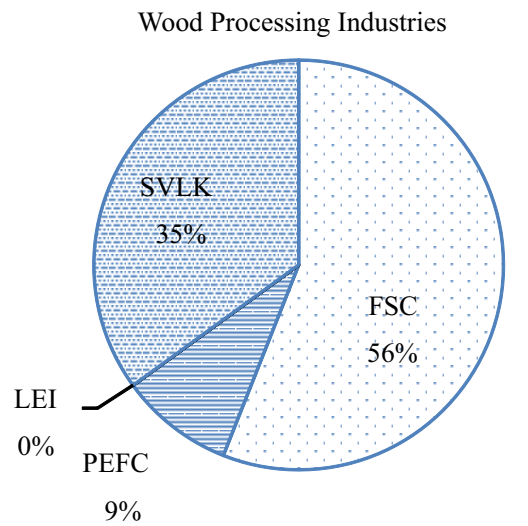

Figure 4 The schemes preferred by the customers of each stakeholder type. 
authority to interpret the ways in which those standards must be met. Hence, one certification body can have easier assessments and another can have more complicated ones (Gulbrandsen 2004). The challenges for the FSC in becoming a friendlier scheme for industries are the limited amount of information smallholders have about it, the difficulty in the interpretation of its standards and its strict evaluation system (Stewart et al. 2003). The PEFC and LEI have intermediate standards and the SVLK has lower standards for sustainable forest management. The LEI standard has detailed requirements and its decision-making process (using AHP) is quite complicated. The SVLK is considered to be the least complicated scheme, since it only requires the presentation of documents establishing legality.

Quality of standards The 4 groups of respondents were of the opinion that the FSC has a higher quality of standards than other schemes (Figure 3). The FSC is known as the golden standard because of its high standards of environmental and social responsibility (Magin 2008). Respondents from the auditor group thought that the FSC (91\%) and PEFC (82\%) have higher standards for sustainable forest management (SFM) as compared to the LEI (68\%) and SVLK (46\%). Quite different results arise from environmental organisations, where about $83 \%$ and $73 \%$ of the respondents say that the FSC and LEI, respectively, have higher standards for SFM than PEFC $(44 \%)$ and SVLK (11\%). A similar result can be observed for the group of academics, for whom the FSC (72\%), PEFC $(72 \%)$ and LEI (54\%) had higher standards than the SVLK $(36 \%)$. In contrast, respondents from the MoEF opined that the PEFC (75\%) and LEI (75\%) have higher standards than the FSC (50\%) and SVLK (50\%).

\section{The schemes preferred by customers of timber producers}

The schemes preferred by customers differ according to the type of respondent (Figure 4). Logging company respondents convey that their customers prefer FSC and SVLK schemes to those of the PEFC and LEI. Something similar happens in the industry group, where $56 \%$ of the respondents express that their customers prefer FSC most often. The FSC was selected by timber producers' customers due to its wellknown reputation, internationally-market acceptance, and because no buyers reject. LEI has detailed standards that are suitable for SFM in Indonesia. However, respondents convey that there is a lesser demand for LEI among customers than there is for other schemes. A respondent from the industry group said that he did not want to engage with the LEI, as it has complicated requirements and is not accepted worldwide (it is only accepted in some countries). Even though LEIcertified products are accepted in Japan, Belgium, French, Italy, Spain, Finland and US (Purbawiyatna \& Simula 2008), the development of LEI certification tended to stagnate in the last 5 years. Wibowo et al. (2014) revealed that LEI's weaknesses originate from its narrow acceptance by buyers, its ineffective form of organisation and the penetration by stronger schemes.

The schemes demanded by the end buyer The four groups of respondents indicated that end buyers prefer the FSC and PEFC as compared to LEI and SVLK (Figure 5). The respondents from the auditors group express that the FSC $(96 \%)$ and PEFC (72\%) have a higher market demand than the SVLK (50\%) and LEI (9\%). A similar opinion came from environmental organisations, where the respondents convey that the FSC (72\%) and PEFC (50\%) have a higher demand than do the SVLK (12\%) and LEI (11\%). The respondents from the academics group have a different view, where $82 \%$ and $63 \%$ of them say that the FSC and SVLK, respectively, have higher market demand than do the PEFC (45\%) and LEI

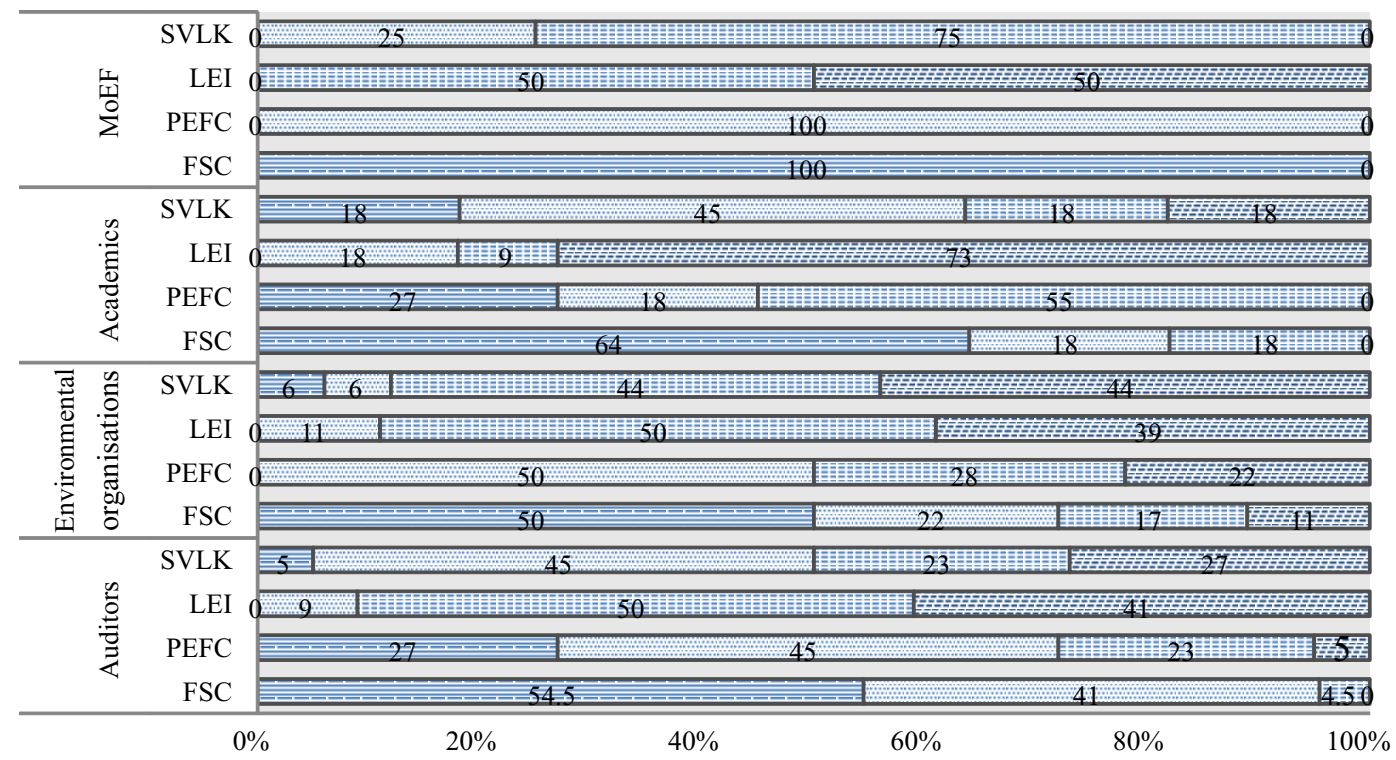

Figure 5 End buyers' demand for different schemes, according to stakeholder type. Very high (目), high (圈), intermediate (国), low (国). 


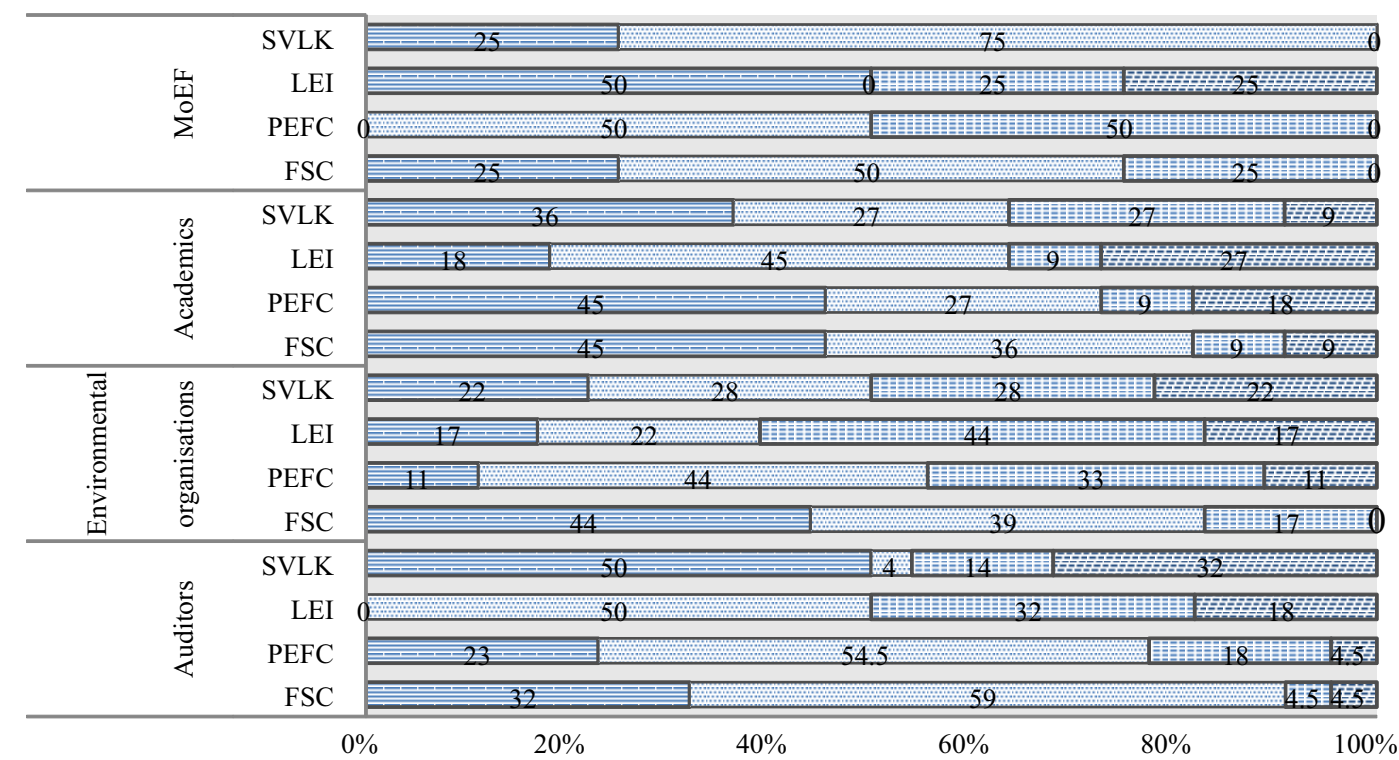

Figure 6 Schemes' support for the sustainability of logging and industry, according to stakeholder type. Very supportive (目), supportive (圆), intermediate (司), less supportive (国).

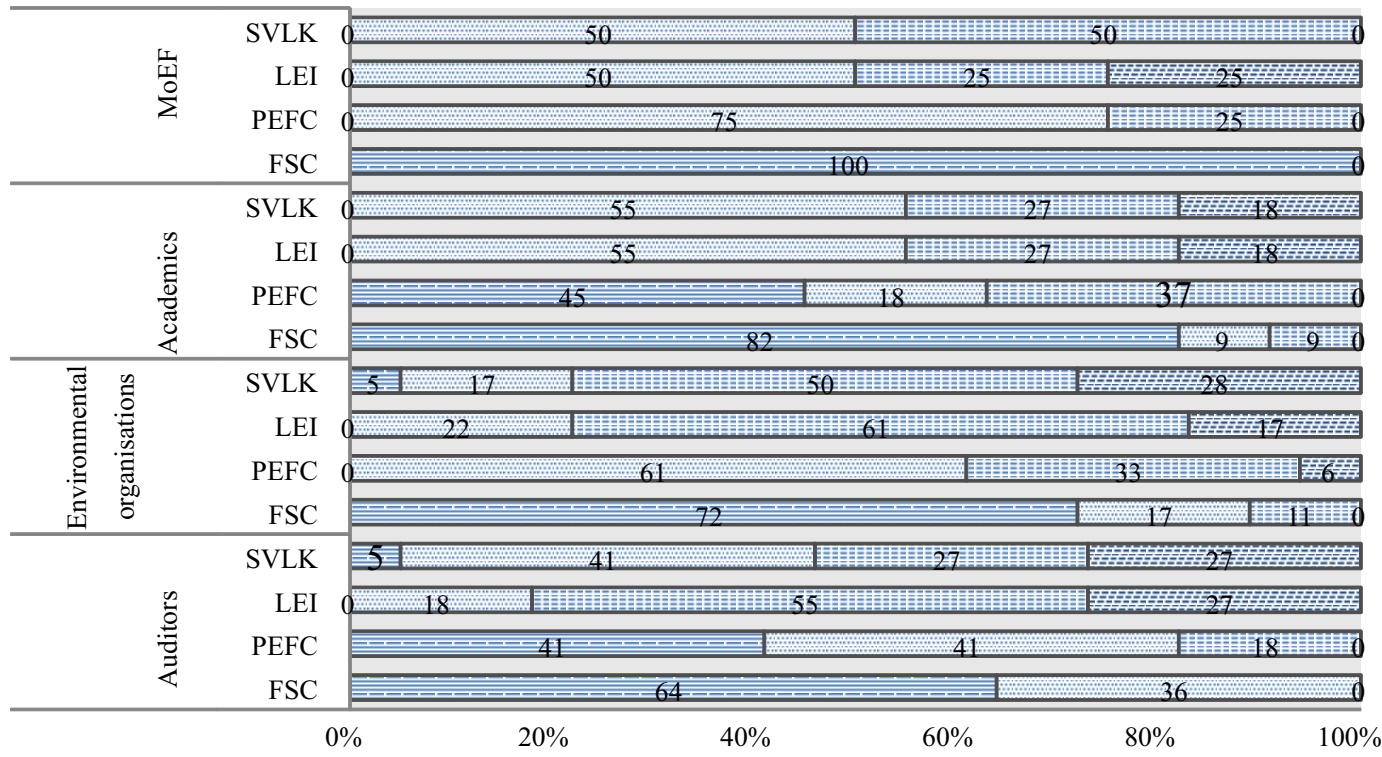

Figure 7 The perception of image branding for each scheme, according to stakeholder type. Very good (目), good (圖), intermediate (国), low (国).

(18\%). The respondents from the MoEF share the opinion of the auditor and EA groups, where all of them (100\%) convey that the FSC and PEFC schemes have a higher market demand than do the SVLK and LEI. However, according to the respondents, the certification only belongs in the international market, and the local market has not really been made aware of the certified and non-certified products. According to a survey by Elliot (2014) in North Carolina, consumers are generally unaware of the concepts of forest certification and certified products.

The schemes that help the sustainability of logging and of wood processing industries Almost all respondents from the 4 different groups acknowledge that the FSC and PEFC are schemes that are more helpful to the logging companies than are the LEI and SVLK (Figure 6). In the group of auditors, about $91 \%$ and $78 \%$ of respondents expressed that the FSC and PEFC are more helpful than are the SVLK (54\%) and LEI (50\%). Similarly, environmental organisations express that the FSC (83\%) and PEFC (55\%) are more helpful than the SVLK (50\%) and LEI (39\%). The results are quite even across the schemes for the group of academics, where a total of $81 \%, 72 \%, 63 \%$ and $63 \%$ of respondents consider the FSC, PEFC, LEI and SVLK, respectively, to be the helpful scheme. In contrast with the other groups, the respondents from the MoEF stated that the 
SVLK is more helpful when compared to FSC, LEI and PEFC. According to a study by Nukpezah et al. (2014), about $63 \%$ of logging companies in Cameroon are certified by FSC. The main incentives for pursuing FSC certification were easy penetration into international markets, tax holiday benefits and the enhancement of the corporate image of the logging companies through corporate social responsibility fulfilments.

Image branding of the schemes About $100 \%$ and $82 \%$ of the respondents from the auditors group, respectively, express that the FSC and PEFC provide better image branding than the SVLK (46\%) and LEI (8\%) (Figure 7). Something similar happens with environmental organisations, where $89 \%$ and $61 \%$ of respondents reported that FSC and PEFC, respectively, have good image branding, while only $22 \%$ and $22 \%$ said the same about SVLK and LEI, respectively. In the group of academics, $91 \%$ of respondents said that the FSC has the best image branding, followed by the PEFC (63\%), SVLK (55\%) and LEI (55\%). The MoEF

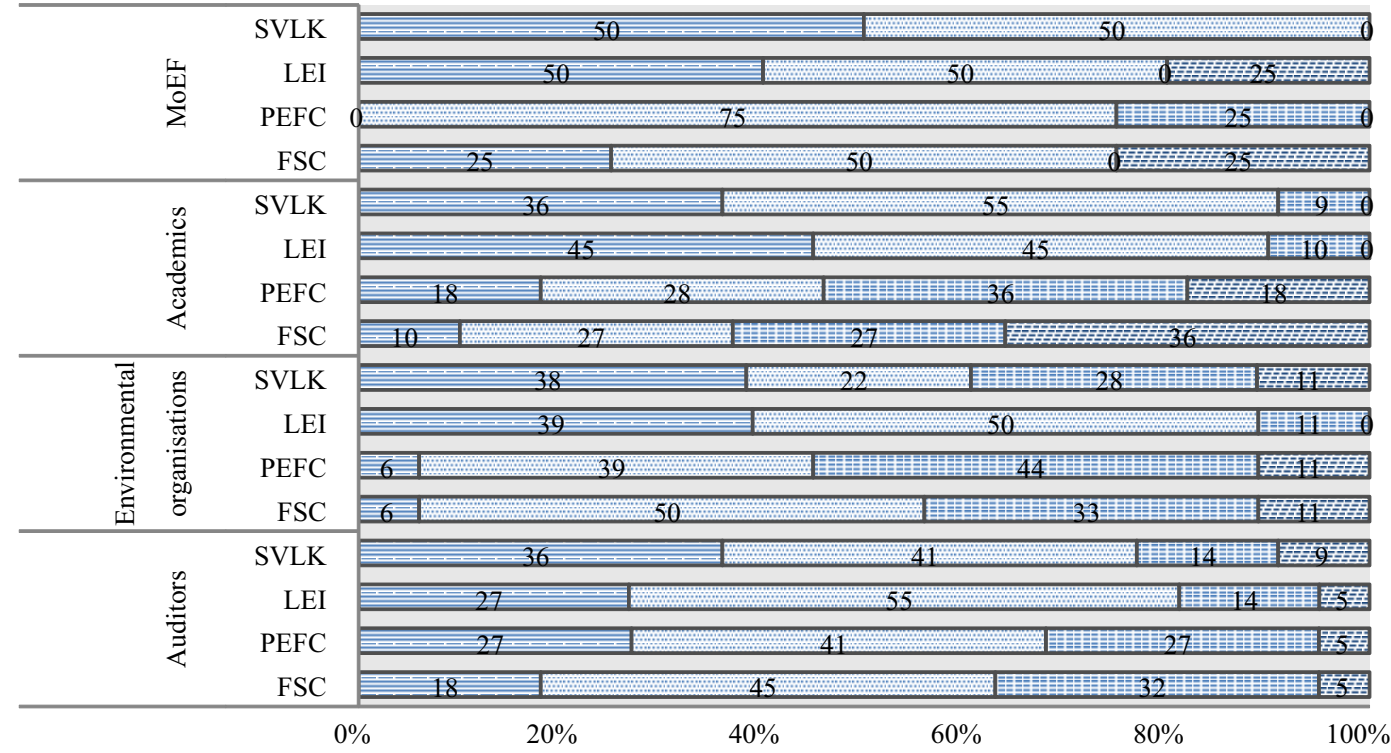

Figure 8 The suitability of each scheme to conditions in Indonesia. Most suitable (目), suitable (圖), intermediate (国), Less suitable preferred (国).

Wood processing associations

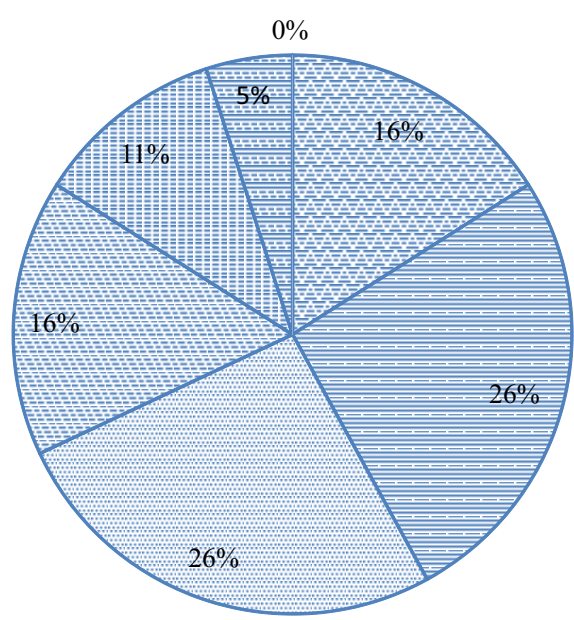

Logging companies

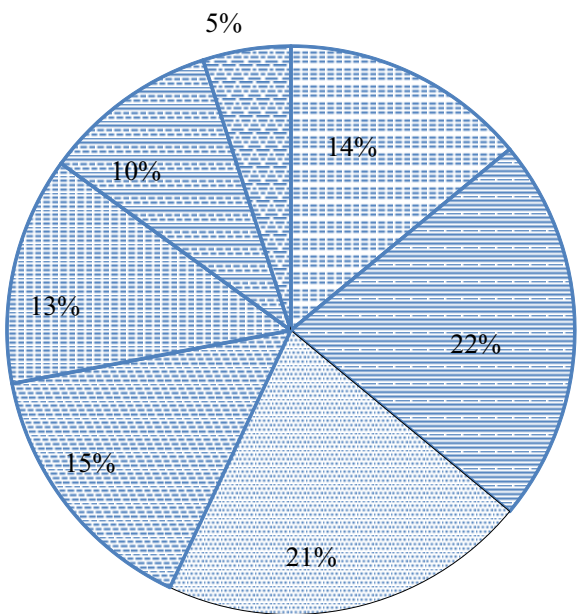

Wood procesing industry

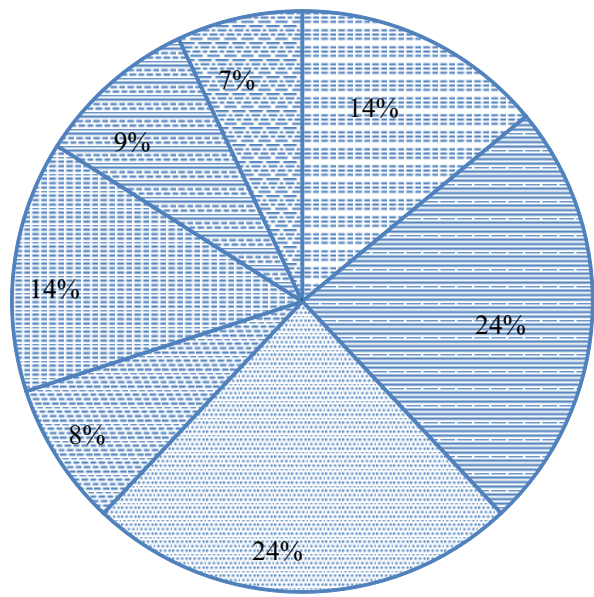

Figure 9 The motivation for pursuing certification. Preferred by business partner (国), support for environment and social aspects (圖), Scheme credibility (国), recommended by NGO ( $\square$ ), Image branding (目), Mandatory/government product (国), Suitable with company profile (国), 
also showed similar results, where $100 \%$ and $75 \%$ of respondents acknowledge that the FSC and PEFC, respectively, have good image branding. Research has shown that FSC certification can achieve improved market access, higher revenues, and an enhanced public image (Fonseca 2006)

The suitability of the schemes to Indonesia's conditions About $82 \%$ and $77 \%$ of respondents from the auditors group said that the LEI and SVLK are more suitable to Indonesia than are the PEFC (68\%) and FSC (63\%) (Figure 8). As a national scheme, LEI and SVLK standards fulfil government regulations, adapt to local conditions and are compliant with international standards. Something similar can be seen in the environmental organisations, where $89 \%$ of respondents express that the LEI is more suitable than SVLK (61\%), FSC $(56 \%)$ and PEFC (45\%). In the group of academics, the respondents said that the SVLK (91\%) and LEI (90\%) are more suitable than the other two schemes, PEFC (46\%), and FSC (37\%). Similarly, in the MoEF group, $100 \%$ of respondents believe that the LEI and SVLK are more suitable than the PEFC and FSC.

The LEI is the most suitable than the PEFC and FSC. The LEI is the most suitable scheme for Indonesia according to the stakeholders as a whole, followed by the SVLK. The LEI has produced high quality documentation of its extensive and carefully structured systems for forest certification (Hinrichs 2005). LEI standards are specific to local conditions and have strong national stakeholder support (Maryudi 2009). IFCC standards are also suitable to the plantation forests in Indonesia and more flexible than those of the FSC. The PEFC, LEI and SVLK focus more on implementing the CoC system with forest conservation, which is limited in FSC, making them therefore more suitable to be applied within the competition in business/industry. With its harmonisation standards, the FSC is not easier to apply. One respondent said the harmonisation standards are helpful, but some verifiers are not applicable to forest management in Indonesia, such as the requirements of High Conservation Value Forests (HCVF), non-timber product management, and worker regulations.

Forest certification caters to many peers and their respective interests (Rametsteiner \& Simula 2003). By obtaining certification, manufacturers are more likely to maintain their current markets (the alternative being to lose them) or enter a new, more environmentally-conscious market (Chen at al. 2011). Figure 9 shows that an improved market and image branding is the main motivation of respondents for procuring certification (similar result to a study by Bowers et al. 2012). Image branding and support for the environment and society were the main motivations for respondents from the WPA group for seeking certification $(26 \%)$. Other reasons are the preferences of business partners, mandatory requirements and scheme credibility and suitability to the company profile. Similar trends happen in the group of logging companies, where $22 \%$ and $21 \%$ of respondents stated that image branding and support for the environment and society were the main motivations. Other motivations were mentioned, namely mandatory requirements, preferences of business partners, scheme credibility, and suitability to the company profile. Astana et al. (2014) show that companies that are involved in voluntary certification see it as a marketing strategy, due to the limited amount of available certified wood. Opinions from the WPI group show the same result, where $24 \%$ of respondents express that image branding and support for the environment and society are the main motivations for becoming certified. Other motivations account for less than $20 \%$ each, namely scheme credibility, preference of business partners, mandatory requirements, and suitability to the company profile. There are also other reasons mentioned by the respondents, such as specific wood, international rules and clear indicators and criteria. Interestingly, $17 \%$ of respondents from logging companies and WPI mentioned

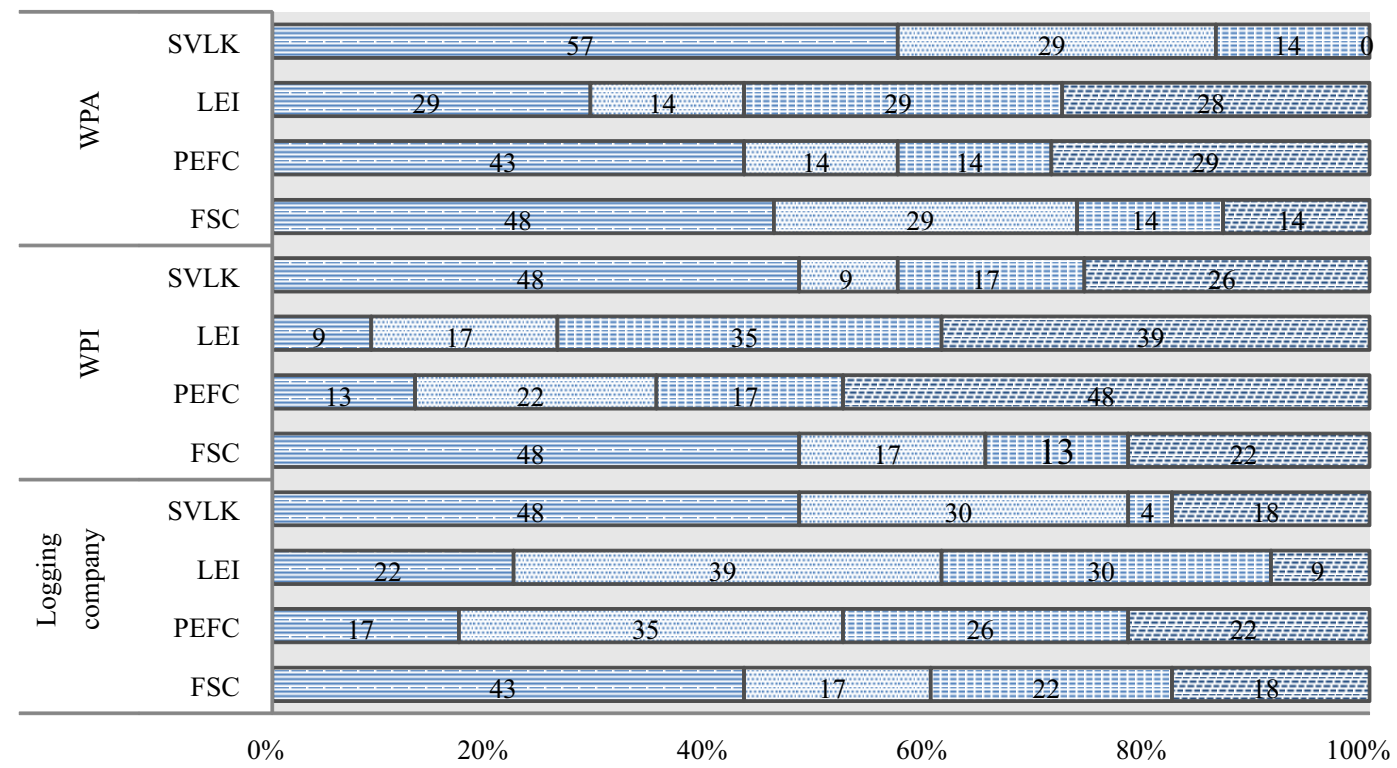

Figure 10 The scheme preference according to actor type. Most preferred (目), Preferred (圈), Intermediate (司), Least preferred (国). 
Table 1 Key features of stakeholders' recognition of and preferences for certification and timber legality systems

\begin{tabular}{lcccc}
\hline \multicolumn{1}{c}{ Key features } & & \multicolumn{2}{c}{ Ranking } & \\
\cline { 2 - 5 } & 1 & 2 & 3 & PEFC \\
\hline Ease of procurement & SVLK & LEI & FSC & SVLK \\
Complexity of requirements & FSC & PEFC & LEI & LEI \\
Quality of standards & FSC & PEFC & PEFC & LEI \\
Demand by customers of timber producer & SVLK & FSC & SVLK & LEI \\
Demand by end buyer & FSC & PEFC & PEFC & SVLK \\
Help to industries and logging companies & FSC & PEFC & SVLK & LEI \\
Good image branding & FSC & FSC & LEI & PEFC \\
Necessary for Indonesia's conditions & SVLK & SVLK & FSC & PEFC \\
Suitability for Indonesia's conditions & LEI & FSC & PEFC & LEI \\
Preferred by stakeholders & SVLK & & \\
\hline
\end{tabular}

FSC $=$ Forest Stewardship Council, PEFC $=$ Programme for the Endorsement of Forest Certification, LEI $=$ Lembaga Ekolabel Indonesia, $\mathrm{SVLK}=$ Sistem Verifikasi Legalitas Kayu

that recommendations from environmental organisations also increase their motivation to become certified.

\section{The scheme preferences based on stakeholder interests As} can be seen in Figure 10, about $78 \%$ and $61 \%$, respectively, of the respondents from the logging company group indicate that SVLK and LEI are preferred over FSC (61\%) and PEFC $(52 \%)$. The industry group shows a different trend, with $65 \%$ and $57 \%$ of respondents expressing their preference for FSC and SVLK, respectively, while the other $35 \%$ and $26 \%$ prefer PEFC and LEI, respectively. Similarly as with the logging company group, the respondents from the wood processing association group preferred SVLK (86\%) and FSC (71\%) to PEFC (67\%) and SVLK (43\%). In addition to it being easy and cheap to obtain, another reason for selecting SVLK is because it is a mandatory system, and it is obligatory for them to use it. The standards for the SVLK are achievable for the conditions of forest management in Indonesia. The government supports the implementation of SVLK by providing a guidance manual and public consultation. The reason for preferring the FSC is because it is accepted in markets worldwide, even if its standards are more complicated. The FSC may be an attractive marketing imperative for companies that seek to penetrate markets in the logging industry (Nukpezah et al. 2014). In Indonesia, the FSC is considered to be closer to natural forest management and community forestry (small holders). The FSC scheme, as the most satisfactory scheme from the point of view of end consumers, on the other hand, needs to adopt local business customs to increase its acceptance by domestic industries (Klassen et al. 2014, Hajjar 2013). On the other hand, the wood processing group preferred PEFC and SVLK to FSC and LEI. Almost no respondents preferred LEI as their scheme because of its complexity and low demand.

\section{Conclusion}

Respondents' feedback on our questionnaire can illustrate how Indonesian stakeholders, mainly in the business sector, recognise four forest certification schemes currently used in Indonesia. In general, respondents consider SVLK to be the easiest scheme to obtain certification, and the most indemand by industries. The reasons for choosing SVLK are: (i) standards suited to forest management practices in Indonesia, (ii) the requirements are easy to fulfil and understand, (iii) the government has made it mandatory, (iv) there are enough certification/verification bodies, and (v) the low cost of the certification process and the availability of subsidies. In contrast, the FSC was identified as the most costly scheme with the most requirements and the most complex standards, but also as the most often demanded by the customers. In brief, the SVLK is evidently preferred by industries for economic and technical reasons, while FSC is preferred due to its good image branding and wide market acceptance. However, this view has to be analysed further to determine whether it is really based on experience or whether it is the result of the influence of the promotion of the FSC by environmental organisations like Greenpeace, the WWF, and others, which regularly produce material that presents the FSC in a positive light. The respondents placed the LEI in between these two schemes, by characterising it as having high standards, a low market demand, complex requirements and a high cost. Although the PEFC scheme is quite new in Indonesia and there are no reports on the companies that have been certified using it, respondents acknowledge that the PEFC is a forest certification scheme with high standards. Surprisingly, the LEI, which most stakeholders do not prefer, was chosen as being the most suitable scheme for sustainable forest management in Indonesia, followed by the SVLK. Both are national forest certification initiatives.

\section{Recommendation}

The existence of many third-party forest certification schemes opens up opportunities for the timber industries to choose the most suitable for them. However, financial 
constraints, the export orientation and the compulsory nature of the SVLK mean that this selection is not always easy. To overcome this complexity, the Ministry of Environmental and Forestry needs to improve the SVLK continually to maintain its status as a credible scheme, ensuring it aims to better forest governance. Comprehensive and proper responses to any objections about the implementation of SVLK and its certification processes should be properly addressed by the government. The FSC and SVLK should be allowed to compete freely and have the same chances to gain broader market recognition. In addition to these wellestablished schemes, the LEI and PEFC are still necessary as an alternative and counterweight for the appropriate enterprises. Synchronization or mutual recognition of the schemes could be more profitable for the forest industries and could help avoid the cost of multiple certifications

\section{Acknowledgment}

The Indonesian Ministry of Education and the German Academic Exchange Service (DAAD) supported this research financially. We sincerely thank $\mathrm{Mr}$ Hartono Prabowo, $\mathrm{Mr}$ Lisman Sumardjani, and $\mathrm{Mr}$ Alan Purbawiyatna, from the Directorate General of Forest Utilization at the Ministry of Environment and Forestry, for their valuable information, which was a great contribution to this article.

\section{References}

Astana S, Obidzinski K, Riva WF, Hardiyanto G, Komarudin H, Sukanda. 2014. Cost and benefit implications of SVLK implementation to small-scale timber sector. Jurnal Penelitian Sosial dan Ekonomi Kehutanan 11(3):175-198.

Bowers T, Eastin I, Ganguly I, Cao J, Seol M. 2012. Forest certification in Asia: The changing marketplace for value-added wood product manufacturers in China and Vietnam. The Forestry Chronicle 88(5):578-584. http://dx.doi.org/10.5558/tfc2012-109.

Chen J, Innes JL, Kozak RA. 2011. An exploratory assessment of the attitudes of Chinese wood products manufacturers towards forest certification. Journal of Environmental Management 92:2984-2992. http://dx. doi.org/10.1016/j.jenvman.2011.07.012.

Elliot J. 2014. An analysis of willingness to pay and reasons for purchasing certified forest products. [Thesis]. North Carolina: The Nicholas School of the Environment of Duke University.

Faggi AM, Zuleta GA, Homberg M. 2014. Motivations for implementing voluntary environmental actions in Argentine forest companies. Land Use Policy 41:541-549. http://dx.doi.org/10.1016/j.landusepol.20 14.04.011.

Fonseca SA. 2006. Forest certification in Mexico. In: Cashore B, Gale F, Meidinger E, Newsom D, editors.
Confronting sustainability: Forest certification in developing and transitioning countries. New Haven: Yale Publishing Services Center.

[FSC] Forest Stewardship Council. 2008. Facts and figures on FSC growth and markets. [download] http://www.ipef.br/pccf/artigos/FSC_Fatos_e_Mercado _Fev_2008_Ingles.pdf.

[FSC] Forest Stewardship Council. 2014. Global FSC certificates: type and distribution. [download] https://ic.fsc.org/preview.facts-and-figures-november2014.a-3810.pdf.

Gulbrandsen, L. 2003. The evolving forest regime and domestic actors: strategic or normative adaptation?. Environmental Politics 12(2):95-114. http://dx.doi.org/ 10.1080/09644010412331308204.

Gulbrandsen LH. 2004. Overlapping public and private governance: Can forest certification fill the gaps in the global forest regimes? Global Environmental Politics 4(2):75-99. http://dx.doi.org/10.1162/1526380043230 74200 .

Hansen E, Fletcher R, Nikinmaa H. 2005. Forest certification and small forest enterprises: key trends and impacts, benefits and barriers. Washington, DC: Forest Trends.

Haufler V. 2003. New forms of governance: certification regimes as social regulations of the global market. Social and political dimensions offorest certification 237-247.

Hinrichs A. 2005. Lembaga Ekolabel Indonesia-Introduction and implementation of forest certification in Indonesia. In: Burger D, Hess J, Lang B, Editors. Forest Certification: An innovative instrument in the service of sustainable development?, Eschborn, Germany: Deutsche Gesellschaft für Technische Zusammenarbeit (GTZ). pp.135-153.

Krott M. 2005. Forest Policy Analysis. Springer, Dordrecht.

[LEI] Lembaga Ekolabel Indonesia. 2014. Laporan Kegiatan Lembaga Ekolabel Indonesia 2009-2014. Jakarta: LEI.

Leslie AD. 2004. The impacts and mechanics of certification. International Forestry Review 6(1):30-39. http://dx.doi. org/10.1505/ifor.6.1.30.32064.

Lozano R. 2013. A holistic perspective on corporate sustainability drivers. Corporate Social Responsibility and Environmental Management 22:32-44. http://dx.doi. org/10.1002/csr.1325.

Magin G. 2008. Forest Certification: What does it mean for the world's forests?. Botanic Gardens Conservation International 5(1). Available online: http://www.bgci.org resources/article/0579/. 
[MoEF] Ministry of Environment and Forestry. 2012. Minister Regulation No. 95/Menhut-II/2012. Standards and guidelines on implementation of performance assessment of sustainable management of production forest and timber legality assurance system (SVLK). Jakarta: Ministry of Environment and Forestry.

Nukpezah D, Alemagi D, Duguma L, Minang P, Mbosso C, Tchoundjeu Z. 2014. An examination of forest certification status among logging companies in Cameroon. Internationan Scholarly Research Notices 2014. Article ID: 323014.

Nurrochmat DR, Dharmawan AH, Obidzinski K, Dermawan A, Erbaugh, JT. 2014. Contesting national and international forest regimes: Case of timber legality certification for community forests in Central Java, Indonesia. Forest Policy and Economics http://dx.doi. org/10.1016/j.forpol.2014.09.008.

Nussbaum R, Simula M. 2005. The Forest Certification Handbook. London: Earthscan.

Obidzinski K, Dermawan A, Andrianto A, Komarudin H, Hernawan D. 2014. The timber legality verification system and the voluntary partnership agreement (VPA) in Indonesia: Challenges for the small-scale forestry sector. Forest Policy and Economics 48:24-32. http://dx.doi. org/10.1016/j.forpol.2014.06.009.

[PEFC] Programme for the Endorsement of Forest Certification. 2014, November. PEFC global statistics: SFM \& CoC certification. Available online: http://www.pefc.org/about-pefc/who-we-are/facts-afigures.

Purbawiyatna A, Simula M. 2008. Developing forest certification: towards increasing the comparability and acceptance of forest certification systems worldwide. International Tropical Timber Organization. Yokohama, Japan.

Rametsteiner E, Simula M. 2003. Forest certification-an instrument to promote sustainable forest management. Journal of Environmental Management 67:87-98. http://dx.doi.org/10.1016/S0301-4797(02)00191-3.

Sahide MAK, Nurrochmat DR, Giessen L. 2015. The regime complex for tropical rainforest transformation: Analysing the relevance of multiple global and regional land use regimes in Indonesia. Land Use Policy 47:408-425. http://dx.doi.org/10.1016/j.landusepol.0 15.04 .030

[SILK] Sistem Informasi Legalitas Kayu. 2014. List of certificate holders. Available online: www.silk.dephut. go.id/index.php/info/iuiphhk.

Steffek J. 2009. Discursive legitimation in environmental governance. Forest Policy and Economics 11(5):313-318. http://dx.doi.org/10.1016/j. forpol. 2009.04 .003 .

Stewart J, Robinson D, Brown L. 2003. Increasing FSC certification for small and low intensity managed forests. Proceedings of XII World Forestry Congress, Quebec, Canada.

Taylor PL. 2005. In the market but not of it: Fair trade coffee and forest stewardship council certification as marketbased social change. World Development 33(1):129-147. http://dx.doi.org/10.1016/j.world dev.2004.07.007.

Thornber K, Plouvier D, Bass S. 1999. Certification: Barriers to benefits. Joensuu: European Forest Institute.

Tuppura A, Toppinen A, Puumalainen K. 2015. Forest certification and ISO 14001: Current state and motivation in forest companies. Business Strategy and the Environment.

Upton C, Bass S. 1995. The Forest Certification Handbook. London: Earthscan.

van Kooten GC, Nelson HW, Vertinsky I. 2005. Certification of sustainable forest management practices: a global perspective on why countries certify. Forest Policy and Economics 7(6):857-867. http://dx.doi.org/10.1016/ j.forpol.2004.04.003.

Wibowo A, Sahide MAK, Pratiwi S, Dharmawan B, Giessen L. 2014. Positioning LEI among certification schemes and developing options for its transformation. Paper presented at the Third Congress of the Indonesian Ecolabelling Institute, held in Bogor, 9 October 2014. 